Article

\title{
In Vitro Study of Multi-Therapeutic Properties of Thymus bovei Benth. Essential Oil and Its Main Component for Promoting Their Use in Clinical Practice
}

\author{
Sherif T. S. Hassan ${ }^{1, *(\mathbb{D})}$, Kateřina Berchová-Bímová ${ }^{2}$, Miroslava Šudomová $^{3}$, Milan Malaník ${ }^{1}$, \\ Karel Šmejkal ${ }^{1}$ and Kannan R.R. Rengasamy ${ }^{4}$ (i) \\ 1 Department of Natural Drugs, Faculty of Pharmacy, University of Veterinary and Pharmaceutical Sciences \\ Brno, Palackého tř. 1946/1, Brno 612 42, Czech Republic; milan.malanik@seznam.cz (M.M.); \\ karel.mejkal@post.cz (K.Š.) \\ 2 Department of Applied Ecology, Faculty of Environmental Sciences, Czech University of Life Sciences \\ Prague, Kamýcká 129, 16521 Praha 6-Suchdol, Czech Republic; berchova@fzp.czu.cz \\ 3 Museum of literature in Moravia, Klášter 1, 664 61, Rajhrad, Czech Republic; sudomova@post.cz \\ 4 REEF Environmental Consultancy Services, \#2 Kamaraj Street, S.P. Nagar, Puducherry 605 001, India; \\ cr.ragupathi@gmail.com \\ * Correspondence: sherif.hassan@seznam.cz; Tel.: +420-774-630-604
}

Received: 2 September 2018; Accepted: 12 September 2018; Published: 15 September 2018

\begin{abstract}
Thymus bovei Benth. (TB) is an important plant in the traditional medicine of the Mediterranean region. This study investigates the health-promoting properties of TB essential oil (TB-EO) for its possible use in clinical practice with regards to its cytotoxic, anti-herpes simplex virus type 2 (HSV-2), and antihypertensive (through inhibition of human angiotensin-converting enzyme; ACE) properties. The phytochemical profile of EO (99.9\%) was analyzed by Gas Chromatography with Flame-Ionization Detection (GC-FID) and Gas Chromatography-Mass Spectrometry (GC-MS). In this study, all biological methods were performed at the level of in vitro studies. The results showed that TB-EO exerted remarked cytotoxic properties against human cervical carcinoma cells, colon cancer cells, and lung adenocarcinoma cells with the half-maximal inhibitory concentration $\left(\mathrm{IC}_{50}\right)$ values of $7.22,9.30$, and $8.62 \mu \mathrm{g} / \mathrm{mL}$, respectively, in comparison with that of standard anticancer drug cisplatin with $\mathrm{IC}_{50}$ values of $4.24,5.21$, and $5.43 \mu \mathrm{g} / \mathrm{mL}$, respectively. Fascinatingly, TB-EO showed very weak cytotoxicity on the healthy human fetal lung fibroblast cells with an $\mathrm{IC}_{50}$ value of $118.34 \mu \mathrm{g} / \mathrm{mL}$ compared with that of cisplatin $\left(\mathrm{IC}_{50}=10.08 \mu \mathrm{g} / \mathrm{mL}\right)$. TB-EO, its main component geraniol, TB-EO combined with acyclovir (ACV) along with standard ACV, have displayed pronounced inhibitory properties against the replication of HSV-2 with the half-maximal effective concentration $\left(\mathrm{EC}_{50}\right)$ values of $2.13,1.92,0.81$ and $1.94 \mu \mathrm{g} / \mathrm{mL}$, respectively, with corresponding selectivity indices (SI) 98.59 , $109.38,259.26$ and 108.25, respectively. TB-EO and geraniol at a concentration of $15 \mu \mathrm{g} / \mathrm{mL}$ showed prominent inhibitory activities against ACE with \% of inhibition $95.4 \%$ and $92.2 \%$, respectively, compared with that of standard inhibitor captopril $(99.8 \% ; 15 \mu \mathrm{g} / \mathrm{mL})$. Molecular docking studies were performed to unveil the mechanism of action of geraniol as well as structural parameters necessary for anti-HSV-2 activity (through the inhibition of HSV-2 protease) and ACE inhibition. This is the first report on the chemical composition of Egyptian TB-EO along with the above-mentioned biological activities. Our results may be considered as novel findings in the course of a search for new and active anticancer, anti-HSV-2 and antihypertensive agents, and expand the medicinal value of this plant and its phytochemicals in clinical practice.
\end{abstract}


Keywords: anticancer; antihypertensive; HSV-2; Thymus bovei Benth.; essential oil; phytochemical profile

\section{Introduction}

For decades, plants have been known to be a vital source of natural preparations comprising many biologically active molecules that can be used for various applications, such as food additives and health-promoting agents in the form of functional foods and nutraceuticals. Since ancient times, aromatic plants have been widely used as flavorings, and later, they have become a subject for a search of drugs that can be used for the treatment of a wide range of diseases [1,2]. Thymus bovei Benth. (Lamiaceae), commonly known as "Thyme" is a medicinal and aromatic herb, widely distributed in the eastern Mediterranean regions [3]. This plant is considered to be one of the most important Thymus species, due to its high medicinal and curative characteristics. Traditionally, in the North African region, particularly in Egypt, this plant is being used for the treatment of skin and blood infections as well as curing a wide range of microbial infections [4]. It has been stated that this herb has anthelmintic, expectorant, antispasmodic, antiseptic properties due to its content of essential oil (EO) [5]. Moreover, medicinal properties such as curing of injuries, treatment of upper respiratory tract inflammations, and treatment of anorexia, have also been reported [6]. Plant-derived EOs are expected to possess a good bioavailability due to its lipophilic properties, and hence induce curative activities [7].

In recent years, cancer has become the most severe health issue across the globe and is the major cause of mortality worldwide [8]. In this regard, the search for new effective molecules that exhibit antitumor properties against numerous types of cancer has become one of the main topics in the field of natural product research [9]. Plants and their phytochemicals have a rich history of use, and they play a critical role in the development of sophisticated traditional medicine systems, particularly in cancer therapy [10]. EOs derived from various plant species have shown to exert excellent anticancer properties [11-14]. So far, no reports have demonstrated the anticancer activity of T. bovei.

Genital herpes is an incurable viral sexually transmitted disease, induced by herpes simplex virus type 2 (HSV-2). HSV-2 is an enveloped, double-stranded DNA virus of the Herpesviridae family [15]. This virus contaminates the genital mucosa and causes ulcers and lesions in the genital area. Following the principal infection, the virus creates a life-long latent infection within sensory dorsal root ganglia. The occurrence of recurrent infection is mainly generated by reactivation of latent infection, particularly throughout the deficiency of immunity [16,17]. It has been reported that infection with HSV-2 increases the risk of infection with human immunodeficiency virus (HIV), as well as invasive cervical carcinoma. It is known that nucleoside analogs, such as acyclovir (ACV) and its derivatives penciclovir, famciclovir, cidofovir, valacyclovir, trifluridine, and vidarabine are used to treat the HSV-2 infection [18]. However, the development of resistance to antiherpetic medications along with the undesirable side effects claims for the development of new anti-HSV-2 drugs with assorted mechanisms of action [19].

Angiotensin-converting enzyme (ACE) is a zinc-containing metallopeptidase that can elevate blood pressure by converting the inactive decapeptide angiotensin I to the effective vasoconstrictor angiotensin II, in addition, to degrading the hypotensive peptide bradykinin [20]. Due to the fundamental role of ACE in cardiovascular diseases, it has been an attractive target for drug design [21]. Up to date, no investigations have reported the ability of $T$. bovei-derived EO to diminish the risk of hypertension and coronary heart disease by inactivating the enzymatic properties of ACE.

The purpose of this study was to explore the cytotoxic, anti-HSV-2 and antihypertensive activities of T. bovei Benth. EO (TB-EO) and its main active compound geraniol, along with characterization of the phytochemical profile of $\mathrm{EO}$ as well as the quantitative analyses of total possible bioactive compounds present in hydro-ethanolic and aqueous extracts of the plant (total phenolics, total flavonoids, and total proanthocyanidins). Up to date, no previous studies were reported on the metabolic profile of Egyptian T. bovei EO along with the above-mentioned pharmacologic properties. Therefore, in this 
study, we present the first report on such investigations in order to expand the medicinal value of this plant and hence promote its use in clinical use.

\section{Experimental Section}

\subsection{Plant Materials}

Aerial parts of T. bovei Benth. were collected from El-Hammam region $\left(30.841852^{\circ} \mathrm{N} 29.394043^{\circ}\right.$ E), Egypt in Spring 2016. Plant materials have been authenticated by Dr. Sherif T.S. Hassan and voucher specimens (TBB1-2016) were deposited at the Herbarium of the Department of Natural Drugs, Faculty of Pharmacy, University of Veterinary and Pharmaceutical Sciences Brno, Czech Republic.

\subsubsection{EO Extraction}

EO was obtained from air-dried aerial parts $(410 \mathrm{~g})$ by hydro-distillation method using Clevenger-type apparatus for $3 \mathrm{~h}$ following the recommendations of European Pharmacopeia. EO was gained with $1.54 \%$ yield $(v / w)$ [22].

\subsubsection{Phytochemical Profile Analysis of EO by GC and GC-MS}

Gas chromatography (GC; Agilent 6890N, Santa Clara, CA, USA) equipped with a flame ionization detector (FID) and gas chromatography-mass spectrometry (GC-MS) utilizing GC (Agilent 5975, Santa Clara, CA, USA) linked with a mass selective detector (Hewlett Packard-MSD5973, Santa Clara, CA, USA) have been used for identification of EO components. Parameters such as the instrumental setup, operational, and chromatographic settings were tracked as described earlier [23]. EO constituents were identified by matching the obtained mass spectra with Mass Finder-4 Library and Wiley GC-MS Library and by comparison with data obtained from the literature [24-26].

\subsection{Quantitative Analyses of Total Bioactive Constituents}

\subsubsection{Extraction Procedure}

The hydro-ethanolic extract of air-dried powder of T. bovei (HETB) was obtained by maceration for 3 days using ethanol:water $(70: 30 \mathrm{v} / \mathrm{v})(1 \mathrm{~g} / 10 \mathrm{~mL})$, while the aqueous extract of air-dried powder T. bovei (AETB) $(1 \mathrm{~g} / 10 \mathrm{~mL})$ was prepared by boiling in distilled water for $30 \mathrm{~min}$ and left to stand to cool down at $26^{\circ} \mathrm{C}$. The solutions were filtered by Sartorius 388 filter paper and the filtered extracts were employed for analyses.

Total Phenolic Content (TPC)

Folin-Ciocalteu method was used to determine the total phenolic contents (TPC) of HETB and AETB as described earlier [27]. TPC value was expressed as gallic acid equivalents (GAE) (mg GAE/g dry weight of plant material $)\left(R^{2}=0.99\right)$. Experiments were conducted in triplicate.

Total Flavonoid Content (TFC)

The total flavonoid content (TFC) of HETB and AETB was assessed and expressed as rutin equivalents following the method by Hassan et al. [28]. TFC value was expressed as rutin equivalents (RE) $\left(\mathrm{mg} \mathrm{RE} / \mathrm{g}\right.$ dry weight of plant material) $\left(R^{2}=0.99\right)$. Experiments were assayed in triplicate.

Total Proanthocyanidin Content

The $\mathrm{HCl}$ /butan-1-ol assay was achieved to determine the total amount of proanthocyanidin in HETB and AETB and the total value was expressed as $\mu \mathrm{g}$ cyanidin chloride/g dry weight of plant material as previously described [29]. All measurements were analyzed in triplicates. 


\subsection{Cytotoxicity Profile against Human Carcinoma Cells}

\subsubsection{Cell Lines, Medium and Reagents}

Human cervical carcinoma cells (HeLa-R2), colon cancer cells (LS-174-D3), lung adenocarcinoma cells (A-549-C5), and normal human fetal lung fibroblast cells (MRC-5) were courtesy by Motol University Hospital (MUH), Prague, Czech Republic. The cells were cultivated as monolayer culture in a culture medium (Roswell Park Memorial Institute RPMI;1640; Sigma Chemicals Co., Saint Louis, MO, USA) supplied with streptomycin (200 mg/mL), penicillin (192 U/mL), L-glutamine (3 mM), 4-(2-hydroxyethyl) piperazine-1-ethanesulfonic acid (HEPES) (25 mM), and 10\% of heat-inactivated fetal calf serum (FCS) at $\mathrm{pH}=7.2$. Further, the human cancer cells were grown in $5 \% \mathrm{CO}_{2}$ and humidified condition at $37^{\circ} \mathrm{C}$, and subsequently sub-cultured twice for a week as previously described [30].

\subsubsection{Cytotoxicity Assay}

The potential cytotoxic effect of TB essential oil (TB-EO) on various human carcinoma cells along with normal human fetal lung fibroblast cells was screened by MTT assay (3-(4,5-dimethy 1thiazol-2-yl)-2,5-diphenyltetrazolium Bromide) (Sigma-Aldrich, Berlin, Germany) as described earlier [30]. Cisplatin, a standard chemotherapy drug was selected as a reference control (SigmaAldrich, Prague, Czech Republic). The absorbance of the samples was detected at $570 \mathrm{~nm}$ using a microplate reader (Infinite M200, Tecan, Salzburg, Austria). Determination of the half-maximal inhibitory concentrations $\left(\mathrm{IC}_{50}\right)$ was acquired from the cell survival diagrams that necessitate suppressing $50 \%$ of cell survival.

\subsection{Antiviral Activity against HSV-2}

\subsubsection{Viral Strains, Cell Lines, Medium, and Reagents}

Vero cells (ATCC: CCL 81TM, UK; were gained from MUH, Prague, Czech Republic) were grown and prepared as previously described [31]. A clinical isolate of HSV-2 (obtained from HSV-2 infected patients) was kindly acquired from MUH, Prague, Czech Republic. The clinical strain was typed, identified, propagated in Vero cells, and the titers, which are expressed as $50 \%$ tissue culture infective dose $\left(\mathrm{TCID}_{50} / \mathrm{mL}\right.$ ), were assayed by cytopathic end-point method following the same procedures by Hassan et al. [31]. Viral stocks were stored at $-80^{\circ} \mathrm{C}$.

\subsubsection{Determination of Cytotoxicity}

The cytotoxicity was assayed by treating Vero cell monolayers with TB-EO, geraniol (SigmaAldrich, Prague, Czech Republic; Figure 1), and TB-EO with ACV (Sigma-Aldrich, Prague, Czech Republic) in combination, as well as standard ACV using the neutral red dye-uptake method as previously described [31]. The $50 \%$ cytotoxic concentrations $\left(\mathrm{CC}_{50}\right)$ of test compounds were determined as the concentration that diminishes cell viability by $50 \%$ when compared to the untreated controls.

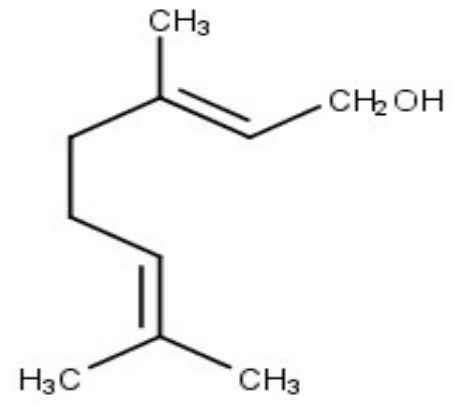

Figure 1. Chemical structure of geraniol. 


\subsubsection{Antiviral Activity Against HSV-2}

Antiherpetic properties of TB-EO, geraniol, and TB-EO combined with ACV against HSV-2 replication were assayed by the titer reduction method as previously described [31]. ACV was used as a reference antiherpetic drug. The $50 \%$ effective concentration $\left(\mathrm{EC}_{50}\right)$ was assessed as the concentration needed for $50 \%$ protection towards virus-induced cytopathic effects. Subsequently, a selectivity index (SI) was calculated as the ratio $\mathrm{CC}_{50} / \mathrm{EC}_{50}$.

\subsubsection{Molecular Docking Study of Geraniol into the Binding Site of HSV-2 Protease}

Protein-Ligand Elaboration and Processing of Docking Analysis

The 3D-crystal structure of HSV-2 protease (PDB ID: 1AT3) and 3D-structure of geraniol (SDF file ID: 64Z) were acquired from the RCSB Protein Data Bank. PyRx docking tool within Autodock VINA software (The Scripps Research Institute, La Jolla, CA, USA) was used to evaluate the binding mode of geraniol in the active site of HSV-2 protease. All docking parameters, settings, calculations, protonation conditions, and the overall charges were tracked as previously described [32,33]. All docked complexes were presented graphically by Discovery studio visualizer version 4.0 (BIOVIA, San Diego, CA, USA) [34].

\subsection{Anti-Angiotensin-Converting Enzyme (ACE) Activity}

The catalytic activity of human ACE was assayed spectrophotometrically based on the formation of hippuric acid as a product following the method by Cushman and Cheung [35] with slight modification. Briefly, the activity was initiated by incubating $166 \mathrm{mU} / \mathrm{mL}$ of human ACE (SigmaAldrich, Prague, Czech Republic) prepared in Tris Buffer ( $50 \mathrm{mM}, \mathrm{pH}=8.3)$ with TB-EO, geraniol, and captopril (standard inhibitor) at concentrations of $15 \mu \mathrm{g} / \mathrm{mL}$ for $80 \mathrm{~min}$ at $37^{\circ} \mathrm{C}$. Further, the catalytic reaction took place by adding the mixture to $110 \mu \mathrm{L}$ of the $10 \mathrm{mM}$ hippuryl-histidyl-leucine (substrate; from Sigma-Aldrich, Prague, Czech Republic). The absorbance of the hippuric acid was detected at $\lambda$ $228 \mathrm{~nm}$, and the \% inhibition was calculated.

\subsection{Molecular Docking Study of Geraniol into the Binding Site of ACE}

Protein-Ligand Preparation and Processing of Docking Analysis

The 3D-crystal structure of human angiotensin-converting enzyme (ACE) complexed with captopril (PDB ID: 1UZF) and 3D-structure of geraniol (SDF file ID: 64Z) were attained by the RCSB Protein Data Bank. Before performing the docking analysis, we authenticated the docking process by removing the co-crystallized ligand captopril from the PDB (PDB ID: 1UZF) structure and re-docked captopril using PyRx docking tool via Autodock VINA software. This software was used to evaluate the binding mode of geraniol in the active site of human ACE. All docking settings, parameters, calculations, protonation conditions, and the overall charges were followed as previously described [32]. All docked complexes were presented graphically using Discovery studio visualizer version 4.0 (BIOVIA, San Diego, CA, USA) [34].

\section{Results and Discussion}

\subsection{Characterization of EO}

The metabolic profile of TB-EO (99.9\%) is characterized by geraniol (32.3\%), $\alpha$-citral $(27.7 \%)$, $\beta$-citral (12.4\%), thymol (3.8\%), DL-camphor (2.4\%), 1,8-cineole (2.3\%), 3-octanol (2.2\%), camphene $(1.8 \%)$, farnesene $(1.7 \%)$, isocaryophyllene $(1.6 \%), \beta$-ocimene $(1.5 \%), \alpha$-limonene $(1.5 \%), \beta$-myrcene $(1.4 \%), \alpha$-phellandrene (1.4\%), $\beta$-linalool $(1.3 \%), \beta$-pinene $(1.3 \%), \alpha$-terpinene $(1.2 \%)$, and nerolidol $(1.1 \%)$ as the principal components (Table 1$)$. Interestingly, the oxygenated monoterpenes appeared to have the highest percentage (82.2\%), where geraniol (32.3\%), $\alpha$-citral $(27.7 \%)$, and $\beta$-citral $(12.4 \%)$ have 
formed the highest percentage of oxygenated monoterpenes. Monoterpene hydrocarbons were found to be $(10.1 \%)$, while sesquiterpene hydrocarbons were accounted to be $(3.3 \%)$. Moreover, oxygenated sesquiterpenes $(1.1 \%)$ and the non-terpenoid compound 3-octanol $(2.2 \%)$ have been identified. It is worth to declare that our results are in total agreement with those results that have reported geraniol, $\alpha$-citral, and $\beta$-citral as the primary constituents of EO of T. bovei [3]. On the other hand, some investigations have presented carvacrol, thymol, and $p$-cymene as the main metabolites detected in Turkish T. bovei EO $[5,36,37]$. These differences in the chemical composition could be correlated to several aspects including but not limited to the isolation procedures used, the impact of genetic, environmental, climate, and growing conditions, and in addition to the impact of organ age $[23,38,39]$.

Table 1. The metabolic profile of TB-EO.

\begin{tabular}{|c|c|c|c|}
\hline Identified Compounds & T. Bovei Benth. (\%) ${ }^{a}$ & $\mathbf{R R I}^{\mathbf{b}}$ & Identification Process \\
\hline$\alpha$-citral (Trans-citral) & 27.7 & 1140 & $t_{R}, M S$ \\
\hline$\beta$-citral (Cis-citral, neral) & 12.4 & 1194 & $t_{R}, M S$ \\
\hline Geraniol (Lemonol) & 32.3 & 1209 & $t_{R}, M S$ \\
\hline DL-camphor & 2.4 & 1430 & $t_{R}, M S$ \\
\hline 3-octanol & 2.2 & 1461 & $t_{R}, M S$ \\
\hline 1,8-cineole (Eucalyptol) & 2.3 & 1531 & $t_{R}, M S$ \\
\hline Thymol & 3.8 & 1578 & $t_{R}, M S$ \\
\hline$p$-Cymene & 0.1 & 1593 & $t_{R}, M S$ \\
\hline Geranyl isobutyrate & 0.1 & 1681 & $t_{R}, M S$ \\
\hline$\beta$-linalool & 1.3 & 1764 & $t_{R}, M S$ \\
\hline Geranyl propionate & 0.2 & 1915 & $t_{R}$, MS \\
\hline$\alpha$-cyclocitral & 0.2 & 2028 & $t_{R}, M S$ \\
\hline Linalyl acetate (Bergamol) & 0.2 & 2071 & $t_{R}, M S$ \\
\hline Camphene & 1.8 & 2075 & $t_{R}, M S$ \\
\hline Isocaryophyllene & 1.6 & 2107 & $t_{R}, M S$ \\
\hline Farnesene & 1.7 & 2212 & $t_{R}$, MS \\
\hline Dihydrocarveol acetate & 0.1 & 2404 & $t_{R}, M S$ \\
\hline$\beta$-myrcene & 1.4 & 2621 & $t_{R}, M S$ \\
\hline L-borneol & 0.1 & 2801 & $t_{R}, M S$ \\
\hline$\beta$-ocimene & 1.5 & 2839 & $t_{R}, M S$ \\
\hline Nerolidol & 1.1 & 2873 & $t_{R}, M S$ \\
\hline$\alpha$-limonene & 1.5 & 2903 & $t_{R}, M S$ \\
\hline$\alpha$-terpinene & 1.2 & 2944 & $t_{R}, M S$ \\
\hline$\alpha$-phellandrene & 1.4 & 2976 & $t_{R}, M S$ \\
\hline$\beta$-pinene & 1.3 & 2995 & $t_{R}, M S$ \\
\hline Total & 99.9 & & \\
\hline Oxygenated monoterpenes & 82.2 & & \\
\hline Monoterpene hydrocarbons & 10.1 & & \\
\hline Sesquiterpene hydrocarbons & 3.3 & & \\
\hline Oxygenated sesquiterpenes & 1.1 & & \\
\hline Others & 3.2 & & \\
\hline
\end{tabular}

Percentage $(\%)^{\text {a }}$ assessed from flame ionization detector (FID) data for the polar column; RRI ${ }^{\text {}}$ : Relative retention indices calculated against $n$-alkanes on the polar column; $t$, trace $(<0.1 \%) ; t_{R}$ : Retention times of genuine compounds on the HP Innowax column; MS: Mass spectrometry-the identification is based on the comparison of the mass spectra with those of the Wiley and Mass Finder libraries as well as literature data.

\subsection{Characterization of Total Bioactive Compounds}

The quantitative analyses of total bioactive constituents (TPC, TFC, and total proanthocyanidin content) of HETB and AETB were determined spectrophotometrically. The results are shown in Table 2. The contents of all studied phenolic constituents of HETB were observed to be higher than that of AETB. These results suggest the significance of used solvents. The polyphenols are more soluble in ethanol, therefore, HETB gave higher yields than AETB. Our findings agree with the literature, where methanol or ethanol extracts were reported to show the highest levels of total phenolics, flavonoids, and proanthocyanidins $[40,41]$. However, several studies describe the water as the most appropriate 
solvent for the acquisition of the highest phenolic contents from the plant material [42,43]. Our results indicate that $T$. bovei contains a lower amount of phenolic compounds extracted by ethanol with the value of TPC $85.62 \mathrm{mg} / \mathrm{g}$ DW of plant material in comparison with other ethanol extracts of Thymus species. T. vulgaris L. reached the value of TPC $158.0 \mu \mathrm{g} / \mathrm{mg}$ [43], T. serpyllum $113.0 \mathrm{mg} / \mathrm{g}$ [44] and T. pulegioides L. $155.38 \mathrm{mg} / \mathrm{g}$ of HEE [45]. On the other hand, TFC value of T. bovei $(51.23 \pm 0.43 \mathrm{mg} / \mathrm{g})$ was found to be higher than that of different Thymus species by using an ethanol for extraction and the same procedure to determine the TFC values. Nickavar and Esbati [46] have reported the TFC value $50.39 \mu \mathrm{g} / \mathrm{mg}$ for T. pubescens Boiss. \& Kotschy ex Celak., $37.11 \mu \mathrm{g} / \mathrm{mg}$ for T. kotschyanus Boiss. \& Hohen., and $35.21 \mu \mathrm{g} / \mathrm{mg}$ for T. daenensis Celak., respectively. The TPC and TFC values may significantly vary during the season as it was observed in T. longicaulis [47]. The habitat also plays an important role in the total content of the polyphenolics. Jaouadi et al. [48] have described the variation of phenolic constituents of T. capitatus (L.) Hoffmanns. \& Link harvested in six bioclimatic zones and Tohidi et al. [49] have demonstrated the variations in chemical constituents of fourteen Thymus accessions collected from different regions of Iran.

Table 2. Chemical characterization of TPC and TFC and total proanthocyanidins in HETB and AETB.

\begin{tabular}{cccc}
\hline Extract & $\begin{array}{c}\text { TPC (mg GAE/g DW of } \\
\text { Plant Mterial) }\end{array}$ & $\begin{array}{c}\text { TFC (mg RE/g DW of } \\
\text { Plant Material) }\end{array}$ & $\begin{array}{c}\text { Total Proanthocyanidins ( } \mu \mathrm{g} \\
\text { CC/g DW of Plant Material) }\end{array}$ \\
\hline HETB & $85.62 \pm 0.82$ & $51.23 \pm 0.43$ & $135.91 \pm 0.83$ \\
AETB & $74.84 \pm 1.43$ & $40.51 \pm 0.64$ & $110.31 \pm 1.12$ \\
\hline
\end{tabular}

Values are expressed as the mean \pm standard deviation (SD). Experiments were assayed in triplicates. TPC: Total phenolic content; TFC: Total flavonoid content; HETB: Hydro-ethanolic extract of T. bovei; AETB: Aqueous extract of T. bovei; GAE: Gallic acid; RE: Rutin; CC: Cyanidin chloride; DW: Dry weight.

\subsection{Evaluation of Cytotoxicity Properties}

Over the past decade, cancer has shown the capacity to progress resistance to traditional medications, and the growing frequency of drug-resistant cancer imposes an urgent need to operate further research and treatment development. In this study, we assessed the cytotoxicity profile of TB-EO in comparison with the reference chemotherapeutic drug cisplatin towards various human cancer cell lines, along with normal human fetal lung fibroblast cells. The results exposed that TB-EO exerted remarked cytotoxic properties against human cervical carcinoma cells (HeLa-R2), colon cancer cells (LS-174-D3), and lung adenocarcinoma cells (A-549-C5) with $\mathrm{IC}_{50}$ values of 7.22, 9.30, and $8.62 \mu \mathrm{g} / \mathrm{mL}$, respectively, in comparison with that of cisplatin with $\mathrm{IC}_{50}$ values of $4.24,5.21$, and $5.43 \mu \mathrm{g} / \mathrm{mL}$, respectively (Table 3). Among the obtained results, TB-EO showed strong cytotoxicity against HeLa-R2 cells with an $\mathrm{IC}_{50}$ value of $7.22 \mathrm{\mu g} / \mathrm{mL}$. Interestingly, TB-EO showed very weak cytotoxicity on the normal human fetal lung fibroblast cells (MRC-5) with an $\mathrm{IC}_{50}$ value of $118.34 \mu \mathrm{g} / \mathrm{mL}$ compared with that of cisplatin $\left(\mathrm{IC}_{50}=10.08 \mu \mathrm{g} / \mathrm{mL}\right.$ ). This indicates that $\mathrm{TB}-\mathrm{EO}$ has powerful anti-tumor properties on cancer cells and no significant effect on normal cells. The cytotoxic effect of TB-EO used in this study could be attributed to the major compounds (geraniol, $\alpha$-citral, $\beta$-citral, and thymol) present in TB-EO. In this study, we present the first report on the cytotoxic activities of Egyptian TB-EO. However, several studies have explored variable data of toxicology profiles of EOs on cancer cells from different Thymus species, except $T$. bovei [50-52], we cannot compare our results with them due to the variation in test methods used, as well as different cell lines sources and samples used. Finally, our results suggest that TB-EO might be used to treat cancer without affecting normal cells. 
Table 3. Cytotoxic effect of TB-EO on human cancer cell lines.

\begin{tabular}{ccccc}
\hline \multicolumn{5}{c}{ IC $_{\mathbf{5 0}}(\boldsymbol{\mu g} / \mathrm{mL})$} \\
\hline Compound & HeLa-R2 & LS-174-D3 & A-549-C5 & > MRC-5 \\
\hline TB-EO & $7.22 \pm 1.21$ & $9.30 \pm 0.84$ & $8.62 \pm 1.41$ & $118.34 \pm 0.56$ \\
Cisplatin & $4.24 \pm 0.81$ & $5.21 \pm 0.23$ & $5.43 \pm 0.34$ & $10.08 \pm 0.71$ \\
\hline
\end{tabular}

Values presented are means \pm standard deviation (SD) of three independent experiments performed in triplicates. HeLa-R2: Human cervical carcinoma cells; LS-174-D3: Colon cancer cells; A-549-C5: Lung adenocarcinoma cells; MRC-5: Normal human fetal lung fibroblast cells; TB-EO: T. bovei essential oil; $\mathrm{IC}_{50}$ : The concentration of drug that possesses $50 \%$ inhibition of cell survival.

\subsection{Antiviral Activities against HSV-2 Replication}

Prior to carrying out the anti-HSV-2 assay, we evaluated the cytotoxicity of TB-EO, geraniol, TB-EO combined with ACV as well as standard ACV in Vero cells by the neutral red dye-uptake technique. The selectivity index is vital to control the probable toxic property of any medication on the cells that could be confused with an antiviral activity. The $\mathrm{CC}_{50}$ values of test compounds were determined to be greater than $210 \mu \mathrm{g} / \mathrm{mL}$ (Table 4). Antiherpetic activity was assayed in infected Vero cells, by titer reduction assay using quantitative real-time reverse transcription PCR. TB-EO, geraniol, TB-EO combined with ACV along with standard ACV, have displayed pronounced inhibitory properties against the replication of HSV-2 with $\mathrm{EC}_{50}$ values of 2.13, 1.92, 0.81 and $1.94 \mu \mathrm{g} / \mathrm{mL}$, respectively with corresponding selectivity indices 98.59, 109.38, 259.26 and 108.25 (Table 4). Our findings declare that geraniol (an active constituent in TB-EO) possesses similar anti-HSV-2 activity $\left(\mathrm{EC}_{50}=1.92 \mu \mathrm{g} / \mathrm{mL}\right.$; SI: 109.38$)$ compared with that of $\mathrm{ACV}\left(\mathrm{EC}_{50}=1.94 \mu \mathrm{g} / \mathrm{mL}\right.$; SI: 108.25). Interestingly, TB-EO with ACV in combination exhibited a great synergy effect, which in turn enhanced the potency of antiherpetic activity against HSV-2 replication $\left(\mathrm{EC}_{50}=0.81 \mu \mathrm{g} / \mathrm{mL} ; \mathrm{SI}: 259.26\right)$ compared with that of ACV $\left(\mathrm{EC}_{50}=1.94 \mu \mathrm{g} / \mathrm{mL}\right.$; SI: 108.25). On the other hand, TB-EO exerted lower anti-HSV-2 activity $\left(\mathrm{EC}_{50}=2.13 \mu \mathrm{g} / \mathrm{mL}\right.$; SI: 98.59$)$ than $\mathrm{ACV}\left(\mathrm{EC}_{50}=1.94 \mu \mathrm{g} / \mathrm{mL}\right.$; SI: 108.25).

Table 4. Antiviral activity of TB-EO, geraniol, and TB-EO with ACV in combination against HSV-2 replication.

\begin{tabular}{cccc}
\hline Test Compounds & $\mathrm{CC}_{\mathbf{5 0}}(\mu \mathrm{g} / \mathrm{mL})$ & $\mathrm{EC}_{\mathbf{5 0}}(\mu \mathrm{g} / \mathrm{mL})$ & SI \\
\hline TB-EO & $>210$ & $2.13 \pm 0.63$ & $>98.59$ \\
Geraniol & $>210$ & $1.92 \pm 0.84$ & $>109.38$ \\
AC-EO combined with ACV & $>210$ & $0.81 \pm 1.21$ & $>259.26$ \\
ACV & $>210$ & $1.94 \pm 0.41$ & $>108.25$ \\
\hline
\end{tabular}

Values demonstrated are means \pm standard deviation (SD) of three independent experiments conducted in duplicate. TB-EO: T. bovei essential oil; ACV: Acyclovir; $\mathrm{CC}_{50}$ : $50 \%$ cytotoxic concentration; $\mathrm{EC}_{50}$ : $50 \%$ effective concentration; SI: Selectivity index (calculated as the ratio $\mathrm{CC}_{50} / \mathrm{EC}_{50}$ ). Experiments were performed in duplicate in three independent experiments. PRISM software version 5.0 (GraphPad Software, Inc., La Jolla, CA, USA) was used for statistical analysis (one-way ANOVA test) and to calculate $\mathrm{EC}_{50}$ and $\mathrm{CC}_{50}$ parameters.

In recent years, natural products have attracted the attention of the pharmaceutical industry as an alternative or complementary therapy to the currently existing ones for the treatment of viral infections [19]. The current pharmacologic treatment of HSV infections is based on the use of ACV and related synthetic nucleoside analogs, which interact with viral DNA replication via activation by viral thymidine kinase [33]. The increasing use of antiviral drugs to treat HSV infections has resulted in drug resistance problem, which in return has switched the attention to plant-derived products in clinical practice [53]. Generally, antiviral medications are categorized into three groups: virucidals, immunomodulators, and antiviral chemotherapeutic drugs [19]. Based on the obtained results, we might classify the test compounds as antiviral chemotherapeutic agents. It has been stated that the resistance to antiviral drugs can be overcome by merging them with compounds from different classes of origin $[54,55]$. Thus, the results gained by combining TB-EO with ACV have led to potent anti-HSV-2 
properties along with less resistance. Remarkably, TB-EO, geraniol, and TB-EO combined with ACV seem to be anti-HSV-2 drugs of future that could be used for the treatment of HSV-2 infection.

\subsection{Molecular Interactions of Geraniol with HSV-2 Protease}

It is known that HSV-2 encodes a serine protease that is vital for viral replication and hence represents a viable target for therapeutic intervention. Thus, a molecular docking study was carried out to unveil the binding mode of geraniol into the active site of HSV-2 protease (Figure 2). The docking score for geraniol, which is expressed as binding affinity, was recorded to be $-5.4 \mathrm{kcal} / \mathrm{mol}$. The docking results showed that geraniol bound to the active site of HSV-2 protease and hence inhibited the enzyme by establishing a hydrogen bonding contact with the hydroxyl group of geraniol and amino acid residues ASN-A220. Additional hydrophobic and other critical interactions were recognized (Figure 3). As shown in Figure 3, all amino acid residues were previously reported in the active site of HSV-2 protease and are responsible for the stabilization of the enzyme [56]. Since geraniol bound to the active-site of the enzyme, this means that geraniol is competing with the substrate, and hence acts as a competitive inhibitor.

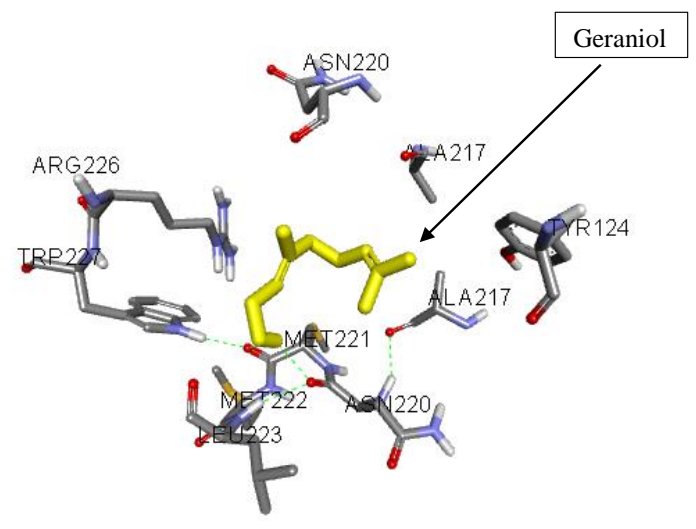

Figure 2. 3D interaction diagram of geraniol in the active cavity of HSV-2 protease.

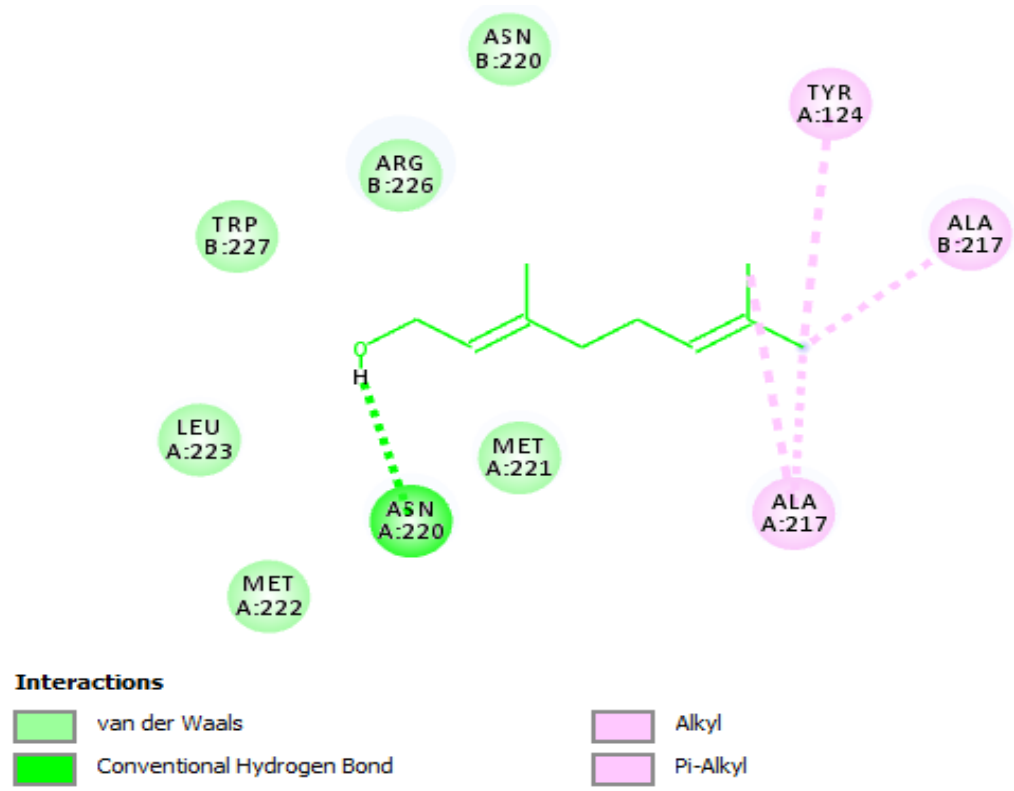

Figure 3. 2D interaction diagram of geraniol in the active cavity of HSV-2 protease. Only those amino acid residues implicated in the enzyme stabilization are exposed. Hydrogen bonding and several substantial interactions with amino acid residues are displayed. 


\subsection{Evaluation of Anti-ACE Properties}

Inhibition of ACE is one of the most imperative strategies to control hypertension and heart failure. The degree of ACE inactivation by TB-EO, geraniol, and captopril was signified by the amount of hippuric acid formed. Based on the estimated percentage of inhibition, TB-EO $(15 \mu \mathrm{g} / \mathrm{mL})$, and geraniol $(15 \mu \mathrm{g} / \mathrm{mL})$ showed prominent inhibitory activities against ACE with \% inhibition 95.4 and 92.2, respectively, compared to captopril $(99.8 \%$ at a concentration of $15 \mu \mathrm{g} / \mathrm{mL}$ ) (Table 5). Since TB-EO inactivated potently the hydrolytic activities of ACE, we decided to test the principal active compound in TB-EO, geraniol for further evaluation against ACE. Based on the obtained results, geraniol remarkably suppressed the hydrolytic properties of ACE. Accordingly, we may suggest that the inhibitory effect of TB-EO on ACE is attributed to the presence of geraniol. In this study, we present a first report on the inhibitory activities of TB-EO and its bioactive molecule geraniol against ACE. Despite limited investigations have confirmed that plant EOs have processed in vitro anti-ACE activities, we tried to rationalize our results with such studies. For instance, Zouari et al. [57] stated that Artemisia herba-alba Asso. EO unveiled in vitro ACE inhibitory action at a concentration of $100 \mu \mathrm{g} / \mathrm{mL}$ (25.4\%). In another study, Ajuga pseudoiva Rob. EO was pronounced to exert a dose-dependent ACE inhibitory activity of $28.3 \%, 53.8 \%$, and $74.5 \%$, at 25,75 and $150 \mu \mathrm{g} / \mathrm{mL}$ of EO, respectively [58]. On the other hand, compounds derived from plant origins such as flavonoids, tannins, and peptides were described with anti-ACE activities [59-61].

Table 5. In vitro ACE inhibitory activities of TB-EO, geraniol, and captopril.

\begin{tabular}{cc}
\hline Compounds & \% Inhibition \\
\hline TB-EO & $95.4 \pm 0.94$ \\
Geraniol & $92.2 \pm 1.14$ \\
Captopril & $99.8 \pm 1.21$ \\
Catalyzed reaction (no inhibition) & $\mathrm{Nd}$
\end{tabular}

Values are presented as the mean \pm standard deviation (SD) ( $n=3)$. TB-EO: T. bovei essential oil; Nd: Not determined.

\subsection{Molecular Interactions of Geraniol with ACE}

To better understand the potency of geraniol for further structure-activity relationship study, molecular docking analysis with ACE was conducted to predict the binding affinity of geraniol into the binding site of ACE (Figure 4), which contributes to rationalize the obtained biological results as well as the mechanism of action. The docking scores for geraniol and captopril, which are expressed as binding affinities, were found to be -5.2 and $-6.1 \mathrm{kcal} / \mathrm{mol}$, respectively. The docking results revealed that geraniol pound to the active cavity of ACE by forming a hydrogen bonding interaction between amino acid residue ASP-415 and the hydroxyl group of geraniol, which in turn resulted in suppressing enzymatic activity (Figure 5). Moreover, several critical interactions were also observed. As shown in Figure 5, all amino acid residues were previously described in the active cavity of human ACE and found to be critical for the stabilization of the enzyme [62]. Although zinc is essential to the catalytic activity of ACE, geraniol did not bind to the zinc active-site and bound to the different active pocket of the enzyme. This means that geraniol is not competing with the substrate, and hence acts as a non-competitive inhibitor by preventing the formation of enzyme-product complexes. 


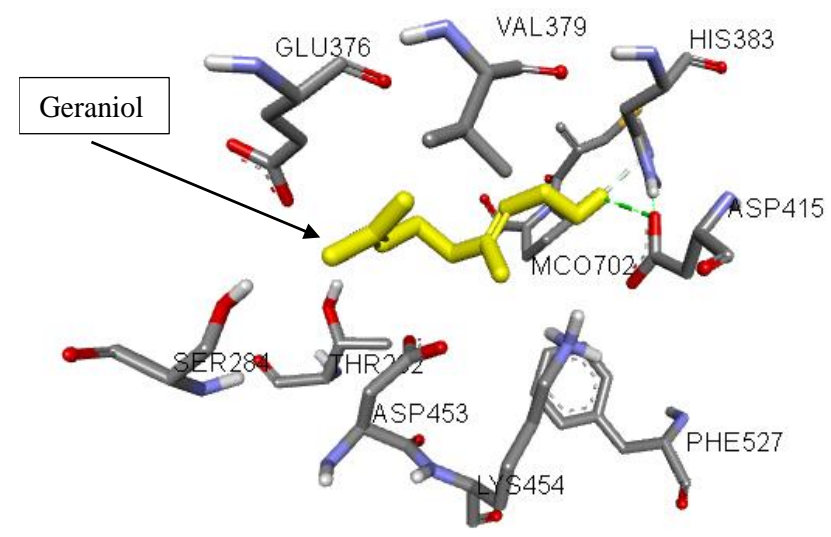

Figure 4. 3D interaction diagram of geraniol in the active cavity of the human ACE.

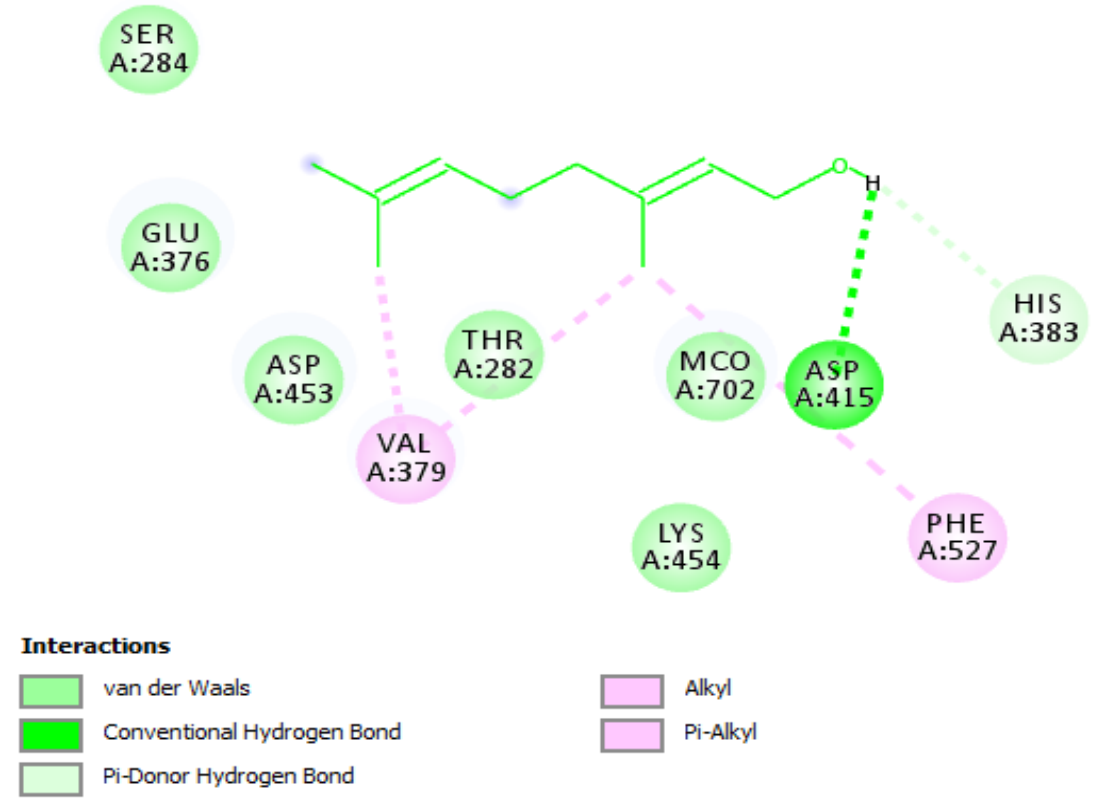

Figure 5. 2D diagram shows the binding mode of geraniol in the active cavity of the ACE. Only those amino acid residues embroiled in ACE stabilization are viewed. Hydrogen bonding and several fundamental interactions with corresponding amino acid residues are presented.

\section{Conclusions}

Recently, plant-derived EOs have attracted the attention of healthcare providers worldwide due to the therapeutic properties against various diseases as well as the safety profiles. Our study showed that T. bovei $\mathrm{EO}$ exerted remarked cytotoxic properties against human cervical carcinoma cells, colon cancer cells, and lung adenocarcinoma cells without affecting normal cells compared with that of cisplatin based on the determination of $\mathrm{IC}_{50}$ concentrations that required to inhibit $50 \%$ of cell survival (see results and discussion section). Additionally, geraniol, the main component of EO, showed prominent inhibition activities against HSV-2 replication and suppressing the activity of ACE (see results and discussion section). Hereby, we present geraniol as a very promising agent in the treatment of genital herpes and hypertension. Subsequently, we confirmed the mechanism of action by using molecular docking studies. These studies have confirmed the basics of phytotherapeutical use of T. bovei in Mediterranean region and its inclusion in North African pharmacopoeias. Finally, further studies should be conducted in vivo and in clinical trials to evaluate efficacy as well as pharmacokinetic and pharmacodynamic properties, leading to effective optimization of TB-EO and geraniol as natural cytotoxic, antiherpetic, and antihypertensive agents. Moreover, large prospective epidemiological studies should be performed. 
Author Contributions: Conceptualization, S.T.S.H. and M.Š.; Methodology, S.T.S.H., K.B.-B., and M.Š.; Software, S.T.S.H.; Validation, S.T.S.H., K.B.-B., M.Š.; Formal Analysis, S.T.S.H., M.Š., and K.B.-B.; Investigation, S.T.S.H., and K.B.-B.; Resources, S.T.S.H., M.Š., and K.B.-B.; Data Curation, S.T.S.H., M.Š., and K.B.-B.; Writing: Original Draft Preparation, S.T.S.H., M.Š., K.B.-B., M.M., K.Š. and K.R.R.R.; Writing: Review and Editing, S.T.S.H., M.Š., K.B.-B., K.Š. and K.R.R.R.; Supervision, S.T.S.H.; Project Administration, S.T.S.H.; Funding Acquisition, S.T.S.H. and K.B.-B.". All authors read and approved the version of the manuscript to be published.

Acknowledgments: This study was partially supported by the Internal Grant Agency (IGA) of the Faculty of Environmental Sciences, Czech University of Life Sciences Prague, Czech Republic. Project No. 20154247/2015.

Conflicts of Interest: The authors have declared that there is no conflict of interest.

\section{References}

1. Li, J.W.; Vederas, J.C. Drug discovery and natural products: End of an era or an endless frontier? Science 2009, 325, 161-165. [CrossRef] [PubMed]

2. McChesney, J.D.; Venkataraman, S.K.; Henri, J.T. Plant natural products: Back to the future or into extinction? Phytochemistry 2007, 68, 2015-2022. [CrossRef] [PubMed]

3. Jaradat, N.; Adwan, L.; K'aibni, S.; Shraim, N.; Zaid, A.N. Chemical composition, anthelmintic, antibacterial and antioxidant effects of Thymus bovei essential oil. BMC Complement. Altern. Med. 2016, 16. [CrossRef] [PubMed]

4. Arab Republic of Egypt. Ministry of Health and Population. The English Text of The Egyptian Pharmacopoeia; Central Administration and Pharmaceutical Affairs, Ministry of Health and Population: Cairo, Egypt, 2005.

5. Tepe, B.; Sarikurkcu, C.; Berk, S.; Alim, A.; Akpulat, H.A. Chemical composition, radical scavenging and antimicrobial activity of the essential oils of Thymus boveii and Thymus hyemalis. Rec. Nat. Prod. 2011, 5, 208-220.

6. Abdel-Hady, N.M.; El-Hela, A.A.; Morsy, T.A. Phenolic content of some selected lamiaceous egyptian medicinal plants: Antioxidant potential and ecological friend mosquito-larvicldal. J. Egypt. Soc. Parasitol. 2014, 44, 21-24. [CrossRef] [PubMed]

7. Nikolic, M.M.; Jovanovic, K.K.; Markovic, T.L.; Markovic, D.L.; Gligorijevic, N.N.; Radulovic, S.S.; Kostic, M.; Glamoclija, J.M.; Sokovic, M.D. Antimicrobial synergism and cytotoxic properties of Citrus limon L., Piper nigrum L. and Melaleuca alternifolia (Maiden and Betche) Cheel essential oils. J. Pharm. Pharmacol. 2017, 69, 1606-1614. [CrossRef] [PubMed]

8. Tang, J.; Hubbard-Lucey, V.M.; Pearce, L.; O'Donnell-Tormey, J.; Shalabi, A. The global landscape of cancer cell therapy. Nat. Rev. Drug Discov. 2018, 17, 465. [CrossRef] [PubMed]

9. Greenlee, H. Natural products for cancer prevention. Semin. Oncol. Nurs. 2012, 28, 29-44. [CrossRef] [PubMed]

10. Kim, C.; Kim, B. Anti-cancer natural products and their bioactive compounds inducing er stress-mediated apoptosis: A review. Nutrients 2018, 10. [CrossRef] [PubMed]

11. Blowman, K.; Magalhães, M.; Lemos, M.; Cabral, C.; Pires, I. Anticancer properties of essential oils and other natural products. Evid. Based Complement. Altern. Med. 2018, 2018. [CrossRef] [PubMed]

12. Andrade, M.; Braga, M.; Cesar, P.; Trento, M.; Esposito, M.; Silva, L. Anticancer properties of essential oils: An overview. Curr. Cancer Drug Targets 2018. [CrossRef] [PubMed]

13. Bayala, B.; Bassole, I.H.; Scifo, R.; Gnoula, C.; Morel, L.; Lobaccaro, J.-M.A.; Simpore, J. Anticancer activity of essential oils and their chemical components-a review. Am. J. Cancer Res. 2014, 4, 591-607. [PubMed]

14. Lesgards, J.F.; Baldovini, N.; Vidal, N.; Pietri, S. Anticancer activities of essential oils constituents and synergy with conventional therapies: A review. Phytother. Res. 2014, 28, 1423-1446. [CrossRef] [PubMed]

15. Desai, D.; Bhutkar, M.; Kulkarni, S. Infectivity and growth kinetics of herpes simplex virus type-2 in MOLT4 CCR5+ and CEM CCR5+ T cell lines. Microb. Pathog. 2018, 123, 82-88. [CrossRef] [PubMed]

16. Troche, G.; Marque Juillet, S.; Burrel, S.; Boutolleau, D.; Bedos, J.P.; Legriel, S. Herpes simplex virus type 2: Cluster of unrelated cases in an intensive care unit. Am. J. Infect. Control 2016, 44, 1178-1180. [CrossRef] [PubMed]

17. Bittencourt Mde, J.; Freitas, L.K.; Drago, M.G.; Carvalho, A.H.; Nascimento, B.A. Cutaneous neonatal herpes simplex virus infection type 2: A case report. An. Bras. Dermatol. 2016, 91, 216-218. [CrossRef] [PubMed] 
18. Cao, S.; Gan, Y.; Dong, X.; Lu, Z. Herpes simplex virus type 2 and the risk of cervical cancer: A meta-analysis of observational studies. Arch. Gynecol. Obstet. 2014, 290, 1059-1066. [CrossRef] [PubMed]

19. Hassan, S.T.; Masarčíková, R.; Berchová, K. Bioactive natural products with anti-herpes simplex virus properties. J. Pharm. Pharmacol. 2015, 67, 1325-1336. [CrossRef] [PubMed]

20. Batty, J.A.; Tang, M.; Hall, M.; Ferrari, R.; Strauss, M.H.; Hall, A.S. Blood pressure reduction and clinical outcomes with angiotensin-converting enzyme inhibitors and angiotensin ii receptor blockers: Protocol for a systematic review and meta-regression analysis. Syst. Rev. 2018, 7, 131. [CrossRef] [PubMed]

21. Cheng, J.; Zhang, W.; Zhang, X.; Han, F.; Li, X.; He, X.; Li, Q.; Chen, J. Effect of angiotensin-converting enzyme inhibitors and angiotensin ii receptor blockers on all-cause mortality, cardiovascular deaths, and cardiovascular events in patients with diabetes mellitus: A meta-analysis. JAMA Intern. Med. 2014, 174, 773-785. [CrossRef] [PubMed]

22. Council of Europe. European Pharmacopoeia, 9th ed.; Council of Europe: Strasbourg, France, 2016.

23. Hassan, S.T.; Švajdlenka, E.; Rengasamy, K.R.; Melichárková, R.; Pandian, S.K. The metabolic profile of essential oils and assessment of anti-urease activity by ESI-mass spectrometry of Salvia officinalis L. S. Afr. J. Bot. 2018. [CrossRef]

24. Adams, R.P. Identification of Essential Oils by Ion Trap Mass Spectroscopy; Academic press: San Diego, CA, USA, 2012.

25. McLafferty, F.W. The Wiley/NBS Registry of Mass Spectral Data; Wiley: New Jersey, NJ, USA, 1989.

26. König, W.; Joulain, D.; Hochmuth, D. Terpenoids and Related Constituents of Essential Oils, Massfinder 3; Convenient and Rapid Analysis of GCMS: Hamburg, Germany, 2004.

27. Tămaş, M.; Toiu, A.; Oniga, I.; Deliu, C.; Oltean, B.; Coldea, G. Quantitative determination of total polyphenols and flavonoids from indigenous species of epilobium of wild origin and 'in vitro' regenerated plantlets. Contrib. Bot. 2009, 44, 119-123.

28. Hassan, S.T.; Berchová, K.; Majerová, M.; Pokorná, M.; Švajdlenka, E. In vitro synergistic effect of Hibiscus sabdariffa aqueous extract in combination with standard antibiotics against Helicobacter pylori clinical isolates. Pharm. Biol. 2016, 54, 1736-1740. [PubMed]

29. Bahorun, T.; Aumjaud, E.; Ramphul, H.; Rycha, M.; Luximon-Ramma, A.; Trotin, F.; Aruoma, O.I. Phenolic constituents and antioxidant capacities of Crataegus monogyna (Hawthorn) callus extracts. Mol. Nutr. Food Res. 2003, 47, 191-198.

30. Supino, R. Mtt assays. In Methods in Moleuclar Biology; Elsevier: New York, NY, USA, 1995; Volume 43, pp. 137-149.

31. Hassan, S.T.; Švajdlenka, E.; Berchová-Bímová, K. Hibiscus sabdariffa L. and its bioactive constituents exhibit antiviral activity against HSV-2 and anti-enzymatic properties against urease by an ESI-MS based assay. Molecules 2017, 22. [CrossRef] [PubMed]

32. Hassan, S.T.; Švajdlenka, E. Biological evaluation and molecular docking of protocatechuic acid from Hibiscus sabdariffa L. as a potent urease inhibitor by an ESI-MS based method. Molecules 2017, 22. [CrossRef] [PubMed]

33. Hassan, S.T.S.; Šudomová, M.; Berchová-Bímová, K.; Gowrishankar, S.; Rengasamy, K.R.R. Antimyco bacterial, Enzyme Inhibition, and Molecular Interaction Studies of Psoromic Acid in Mycobacterium tuberculosis: Efficacy and Safety Investigations. J. Clin. Med. 2018, 7. [CrossRef] [PubMed]

34. Dassault Systèmes BIOVIA. Discovery Studio Modeling Environment, Release 2017; Dassault Systèmes: San Diego, CA, USA, 2017.

35. Cushman, D.W.; Cheung, H.S. Spectrophotometric assay and properties of the angiotensin-converting enzyme of rabbit lung. Biochem. Pharmacol. 1971, 20, 1637-1648. [PubMed]

36. Mansour, S.A.; El-Sharkawy, A.Z.; Abdel-Hamid, N.A. Toxicity of essential plant oils, in comparison with conventional insecticides, against the desert locust, Schistocerca gregaria (Forskål). Ind. Crops Prod. 2015, 63, 92-99. [CrossRef]

37. Aboutabl, E.; Soliman, F.; El-Zalabani, S.; Brunke, E.; El Kersh, T. Essential oils of Thymus bovei Benth. Sci. Pharm. 1986, 54, 43-48.

38. Noroozisharaf, A.; Kaviani, M. Effect of soil application of humic acid on nutrients uptake, essential oil and chemical compositions of garden thyme (Thymus vulgaris L.) under greenhouse conditions. Physiol. Mol. Biol. Plants 2018, 24, 423-431. [CrossRef] [PubMed] 
39. Delgado-Adámez, J.; Garrido, M.; Bote, M.E.; Fuentes-Pérez, M.C.; Espino, J.; Martín-Vertedor, D. Chemical composition and bioactivity of essential oils from flower and fruit of Thymbra capitata and Thymus species. J. Food Sci. Technol. 2017, 54, 1857-1865. [CrossRef] [PubMed]

40. Roby, M.H.H.; Sarhan, M.A.; Selim, K.A.-H.; Khalel, K.I. Evaluation of antioxidant activity, total phenols and phenolic compounds in thyme (Thymus vulgaris L.), sage (Salvia officinalis L.), and marjoram (Origanum majorana L.) extracts. Ind. Crops Prod. 2013, 43, 827-831. [CrossRef]

41. Ali, I.B.E.H.; Bahri, R.; Chaouachi, M.; Boussaïd, M.; Harzallah-Skhiri, F. Phenolic content, antioxidant and allelopathic activities of various extracts of Thymus numidicus Poir. organs. Ind. Crops Prod. 2014, 62, 188-195.

42. Baharfar, R.; Azimi, R.; Mohseni, M. Antioxidant and antibacterial activity of flavonoid-, polyphenol-and anthocyanin-rich extracts from Thymus kotschyanus boiss \& hohen aerial parts. J. Food Sci. Technol. 2015, 52, 6777-6783. [PubMed]

43. Köksal, E.; Bursal, E.; Gülçin, İ.; Korkmaz, M.; Çağlayan, C.; Gören, A.C.; Alwasel, S.H. Antioxidant activity and polyphenol content of Turkish thyme (Thymus vulgaris) monitored by liquid chromatography and tandem mass spectrometry. Int. J. Food Prop. 2017, 20, 514-525. [CrossRef]

44. Mata, A.; Proença, C.; Ferreira, A.; Serralheiro, M.; Nogueira, J.; Araújo, M. Antioxidant and antiacetylcholinesterase activities of five plants used as portuguese food spices. Food Chem. 2007, 103, 778-786. [CrossRef]

45. Taghouti, M.; Martins-Gomes, C.A.; Schäfer, J.; Félix, L.M.; Santos, J.A.; Bunzel, M.; Nunes, F.M.; Silva, A.M. Thymus pulegioides L. as a rich source of antioxidant, anti-proliferative and neuroprotective phenolic compounds. Food Funct. 2018. [CrossRef] [PubMed]

46. Nickavar, B.; Esbati, N. Evaluation of the antioxidant capacity and phenolic content of three Thymus species. J. Acupunct. Meridian Stud. 2012, 5, 119-125. [CrossRef] [PubMed]

47. Galasso, S.; Pacifico, S.; Kretschmer, N.; Pan, S.-P.; Marciano, S.; Piccolella, S.; Monaco, P.; Bauer, R. Influence of seasonal variation on Thymus longicaulis $\mathrm{C}$. Presl chemical composition and its antioxidant and anti-inflammatory properties. Phytochemistry 2014, 107, 80-90. [CrossRef] [PubMed]

48. Jaouadi, R.; Cardoso, S.M.; Silva, A.M.; Yahia, I.B.H.; Boussaid, M.; Zaouali, Y. Variation of phenolic constituents of Tunisian Thymus capitatus (L.) Hoff. et Link. populations. Biochem. Syst. Ecol. 2018, 77, 10-15. [CrossRef]

49. Tohidi, B.; Rahimmalek, M.; Arzani, A. Essential oil composition, total phenolic, flavonoid contents, and antioxidant activity of Thymus species collected from different regions of Iran. Food Chem. 2017, 220, 153-161. [CrossRef] [PubMed]

50. Zu, Y.; Yu, H.; Liang, L.; Fu, Y.; Efferth, T.; Liu, X.; Wu, N. Activities of ten essential oils towards Propionibacterium acnes and PC-3, A-549 and MCF-7 cancer cells. Molecules 2010, 15, 3200-3210. [CrossRef] [PubMed]

51. Ait M'Barek, L.; Ait Mouse, H.; Jaâfari, A.; Aboufatima, R.; Benharref, A.; Kamal, M.; Bénard, J.; El Abbadi, N.; Bensalah, M.; Gamouh, A. Cytotoxic effect of essential oil of thyme (Thymus broussonettii) on the IGR-OV1 tumor cells resistant to chemotherapy. Braz. J. Med. Biol. Res. 2007, 40, 1537-1544. [CrossRef] [PubMed]

52. Nikolić, M.; Glamočlija, J.; Ferreira, I.C.; Calhelha, R.C.; Fernandes, Â.; Marković, T.; Marković, D.; Giweli, A.; Soković, M. Chemical composition, antimicrobial, antioxidant and antitumor activity of Thymus serpyllum L., Thymus algeriensis Boiss. and reut and Thymus vulgaris L. essential oils. Ind. Crops Prod. 2014, 52, 183-190. [CrossRef]

53. Kitazato, K.; Wang, Y.; Kobayashi, N. Viral infectious disease and natural products with antiviral activity. Drug Discov. Ther. 2007, 1, 14-22. [PubMed]

54. Reusser, P. Herpesvirus resistance to antiviral drugs: A review of the mechanisms, clinical importance and therapeutic options. J. Hosp. Infect. 1996, 33, 235-248. [CrossRef]

55. Piret, J.; Boivin, G. Resistance of herpes simplex viruses to nucleoside analogues: Mechanisms, prevalence, and management. Antimicrob. Agents Chemother. 2011, 55, 459-472. [CrossRef] [PubMed]

56. Hoog, S.S.; Smith, W.W.; Qiu, X.; Janson, C.A.; Hellmig, B.; McQueney, M.S.; O’Donnell, K.; O'Shannessy, D.; DiLella, A.G.; Debouck, C.; et al. Active site cavity of herpesvirus proteases revealed by the crystal structure of herpes simplex virus protease/inhibitor complex. Biochemistry 1997, 36, 14023-14029. [CrossRef] [PubMed]

57. Zouari, S.; Zouari, N.; Fakhfakh, N.; Bougatef, A.; Ayadi, M.; Neffati, M. Chemical composition and biological activities of a new essential oil chemotype of Tunisian Artemisia herba alba Asso. J. Med. Plant Res. 2010, 4, 871-880. 
58. Mansour, M.B.; Balti, R.; Rabaoui, L.; Bougatef, A.; Guerfel, M. Chemical composition, angiotensin i-converting enzyme (ACE) inhibitory, antioxidant and antimicrobial activities of the essential oil from south Tunisian Ajuga pseudoiva Rob. Lamiaceae. Process. Biochem. 2013, 48, 723-729. [CrossRef]

59. Balasuriya, B.N.; Rupasinghe, H.V. Plant flavonoids as angiotensin converting enzyme inhibitors in regulation of hypertension. Funct. Foods Health Dis. 2011, 1, 172-188.

60. Liu, J.-C.; Hsu, F.-L.; Tsai, J.-C.; Chan, P.; Liu, J.Y.-H.; Thomas, G.N.; Tomlinson, B.; Lo, M.-Y.; Lin, J.-Y. Antihypertensive effects of tannins isolated from traditional chinese herbs as non-specific inhibitors of angiontensin converting enzyme. Life Sci. 2003, 73, 1543-1555. [CrossRef]

61. Mallikarjun Gouda, K.; Gowda, L.R.; Rao, A.A.; Prakash, V. Angiotensin i-converting enzyme inhibitory peptide derived from glycinin, the $11 \mathrm{~S}$ globulin of soybean (Glycine max). J. Agric. Food Chem. 2006, 54, 4568-4573. [CrossRef] [PubMed]

62. Natesh, R.; Schwager, S.L.; Evans, H.R.; Sturrock, E.D.; Acharya, K.R. Structural details on the binding of antihypertensive drugs captopril and enalaprilat to human testicular angiotensin i-converting enzyme. Biochemistry 2004, 43, 8718-8724. [CrossRef] [PubMed]

(C) 2018 by the authors. Licensee MDPI, Basel, Switzerland. This article is an open access article distributed under the terms and conditions of the Creative Commons Attribution (CC BY) license (http://creativecommons.org/licenses/by/4.0/). 